Ірина Гуменюк,

кандидат філологічних наук, доцент кафедри

педагогіки початкової освіти,

ДВНЗ «Прикарпатський національний університет

імені Василя Стефаника»

(м. Івано-Франківськ, Україна)

\author{
Iryna Humeniuk, \\ $\mathrm{PhD}$ in Philology, Associate Professor, \\ Department of Pedagogy of Primary Education, \\ Vasyl Stefanyc Precarpathian National University \\ (Ivano-Frankivsk, Ukraine) \\ imix@ukr.net \\ ORCID ID 0000-0002-0790-6732
}

УДК 378.881.1: 811.161.2

\title{
РЕТРОСПЕКТИВНИЙ АНАЛІЗ ЗМІСТУ НАВЧАННЯ УКРАЇНСЬКОЇ МОВИ ЗА ПРОФЕСІЙНИМ СПРЯМУВАННЯМ
}

Анотація. Стаття присвячена аналізу еволюційних аспектів розвитку змісту навчальної дисципліни «Українська мова за професійним спрямуванням». Метою публікації є виявлення основних тенденцій формування змісту цієї дисципліни за ретроспективним вектором. У процесі дослідження використано комплекс методів: теоретичні - аналіз та систематизація нормативно-правових актів і літературних джерел для з'ясування ступеня розкриття проблеми в сучасному науковому просторі та ї̈ правового статусу; статистично-описові методи - для виявлення структурних змін у наповненні курсу; методи візуалізації та узагальнення для порівняльного аналізу еволюційних змін у змістовому наповненні аналізованої дисципліни.

Авторка простежила етапи становлення і формування навчального курсу «Українська мова за професійним спрямуванням» 3 моменту його виникнення 1989 року й до сьогодні. Усі зміни в структурі та змістовому наповненні мають нормативно-правовий супровід та обґрунтування. Проаналізовано вихідні навчальні програми курсу й базові підручники. Поряд із виділенням специфіки перших навчальних програм показано основні труднощі в їх реалізації. Еволюційні аспекти змісту УМзаПС виявили себе через спрямування його на формування мовної особистості 3 набором знань, умінь і навичок оптимальної мовної поведінки в професійній сфері. Щодо лінгвістичних знань, отриманих у школі, то вони підлягали узагальненню й систематизації в професійному контексті, але без дублювання.

Відповідно до етапів становлення навчальної дисципліни проаналізовано основні концепції ії розвитку та формування змісту, а також моделі альтернативних курсів. На цій основі здійснено порівняльну характеристику змісту навчання ділової української мови та української мови за професійним спрямуванням.

Ключові слова: українська мова за професійним спрямуванням, професійне спілкування, зміст навчальної дисципліни, комунікативна компетентність, дисципліна за вільним вибором, нормативна дисципліна, фахове становлення.

\section{RETROSPECTIVE ANALYSIS OF THE CONTENT OF TEACHING UKRAINIAN LANGUAGE FOR PROFESSIONAL PURPOSES}

\footnotetext{
Abstract. The article analyses the evolutionary aspects of development of the content of the educational discipline "Ukrainian Language for Professional Purposes". The aim of the publication is detection of the main tendencies of formation of the content of this discipline in the retrospective vector. A set of methods has been used in the research process: theoretical (analysis and systematization of legislative acts and literary sources for clarification of the degree of solving the issue in the modern scientific area and its legal status), statistical and descriptive methods (for detection of structure changes in the content of the course), methods of visualization and generalization (for comparative analysis of evolutionary changes in the content of the analysed discipline).

The author has investigated the stages of formation and development of the educational course "Ukrainian Language for Professional Purposes" from the moment of its appearance in 1989 until now. All changes in the structure and content have legislative accompaniment and substantiation. The main teaching programmes and textbooks of the course have been analysed. Along with highlighting the specificity of the first educational programmes, there have been shown the main difficulties of their implementation.

The evolutionary aspects of the content of the discipline "Ukrainian Language for Professional Purposes" have shown themselves by directing it towards formation of a linguistic personality with a set of knowledge, abilities and skills for optimal language behaviour in professional sphere. Linguistic knowledge obtained at school could be generalized and systemized in professional context, but without duplication.
} 
According to the stages of development of the educational discipline, the main concepts of its formation, development of its content and the model of alternative courses have been analysed. On the basis of it, comparative characteristics of the content of teaching the courses "Business Ukrainian Language" and "Ukrainian Language for Professional Purposes" have been conducted.

Approval of the discipline "Ukrainian Language for Professional Purposes" as a compulsory one had provided wider opportunities for Ukrainian language education of students of all specialities. However, in 2014 the status was changed. This created obstacles for linguistic and communicative education of non-philologist students and caused a new wave of scientific discussion.

Keywords: Ukrainian Language for Professional Purposes, professional communication, content of educational discipline, communicative competence, free choice discipline, compulsory discipline, professional development.

\section{ВСТУП}

Постановка проблеми. Навчальна дисципліна «Українська мова за професійним спрямуванням» 3 моменту її впровадження в навчальний процес ЗВО спричинила виникнення в науковому просторі низки неоднозначних трактувань її мети, призначення та змістового наповнення. Оскільки цей курс і сьогодні залишається єдиним мовознавчим курсом за більшістю освітніх програм підготовки студентів-нефілологів і водночас найбільш адаптивним та мобільним з погляду професійно-мовленнєвої підготовки майбутніх фахівців, актуальною проблемою виявляється з'ясування основних тенденцій у формуванні змісту УМзаПС, зокрема за ретроспективним вектором.

Аналіз наукових досліджень і публікацій. Науковий інформаційний простір піднятої проблеми характеризується наявністю досліджень загального плану (О. Антончук, М. Лісовий, Л. Тищенко, Н. Юрійчук, О. Мельничук, Л. Сілевич, Л. Головата, Л. Костюк, Н. Легкодух), вивчення окремих технологій та підходів викладання УМзаПС (О. Гриджук, Н. Мушировська, І. Романова, О. Тєлєжкіна та ін.), лінгводидактичних праць (Г. Горох, Г. Лукаш, Л. Мельник, Т. Маркотенко, О. Орлова, О. Старова, Т. Панова та ін.), вузькогалузевих досліджень (Т. Лобода, Т. Марцінко, І. Москаленко, В. Рогозіна, А. Савіна, Н. Тоцька та ін.). Однак аналіз та обґрунтування змісту навчання УМзаПС у наукових джерелах відсутній.

\section{МЕТА І ЗАВДАННЯ ДОСЛІДЖЕННЯ}

Метою нашого дослідження $€$ аналіз еволюційних аспектів розвитку змісту навчальної дисципліни «Українська мова за професійним спрямуванням» (УМзаПС) 3 моменту її виникнення до сьогодні. Для досягнення поставленої мети необхідно виконати такі завдання: простежити хронологію виникнення й становлення УМзаПС як навчальної дисципліни, проаналізувати основні навчальні програми й базові підручники, з'ясувати тенденції розвитку змісту УМзаПС, здійснити порівняльний аналіз змісту навчання ділової української мови (ДУМ) та УМзаПС.

\section{МЕТОДИ ДОСЛІДЖЕННЯ}

Для досягнення мети наукового дослідження використано комплекс методів: теоретичні - аналіз та систематизація нормативно-правових актів і літературних джерел для з'ясування ступеня розкриття проблеми в сучасному науковому просторі та її правового статусу; статистично-описові методи - для виявлення структурних змін у наповненні курсу; методи візуалізації та узагальнення для порівняльного аналізу еволюційних змін у змістовому наповненні курсу УМзаПС.

\section{РЕЗУЛЬТАТИ ДОСЛІДЖЕННЯ}

Витоки змістового наповнення УМзаПС простежуються в курсі «Ділова українська мова», запровадженому у вищих навчальних закладах після проголошення незалежності України. Предметний курс ділової мови започатковано підручником «Українське ділове мовлення» (автори: Л. М. Паламар, Г. М. Кацавець), який з'явився 1990 року, як стверджують самі автори, «відповідно до Закону про мови в УРСР, прийнятого 28.10.1989 року», і став «першою в Україні книгою офіційно-ділового спрямування в мовному аспекті» (Паламар Л., Кацавець Г., 1993, с. 287).

Названий підручник було створено за вимогою часу та для забезпечення читання курсу «Українське ділове мовлення», введеного вперше в Україні восени 1989 року Київськими державними курсами іноземних мов «нтерлінгва».

«У 1991 році вийшло друге видання цієї ж книги у Київському видавництві «Укрвузполіграф». I того ж року, за ініціативою завідувача кафедри філології, професора Л. М. Паламар, курс ділового мовлення почали читати у Київському національному університеті імені Тараса Шевченка.

Книга та курс ділового мовлення успішно пройшли апробацію серед слухачів та студентів. I в 1993 році книгу було перероблено, доповнено та названо «Мова ділових паперів» (К., вид-во «Либідь»). Рішенням Міністерства освіти і науки України книгу затверджено як навчальний посібник для вищих навчальних закладів, на базі нього розроблено й затверджено навчальну програму і впроваджено предметний курс «Українське ділове мовлення» у систему освіти України» (Паламар Л., Кацавець Г., 1993, с. 287).

Зміст аналізованого підручника мав виразне мовне спрямування, причому чітко наголошувалося на неправомірності підміни українського ділового мовлення діловодством чи машинописом, що часто спостерігалося в багатьох тодішніх вищих навчальних закладах.

На основі підручника Л. М. Паламар та Г. М. Кацавець створюють два варіанти програми дисципліни «Українське ділове мовлення», розширюючи тим самим методичні можливості викладачів, які можуть пристосувати курс до професійного спрямування факультету чи навчального закладу, а також до рівня підготовки студентів. 
Програма Л.М. Паламар орієнтує на роздільне подання матеріалу: лекційний курс 18 год, практичний - 36 год, самостійна робота - 16 год. Програма охоплює фонетичні й акцентуаційні аспекти української мови, тобто в цьому напрямку фактично дублює шкільний курс. Однак лексичні та синтаксичні особливості розглядаються в контексті усного й писемного ділового мовлення. Прикметно, що окремо виділяється питання «Робота з термінами фаху», яке дає можливість адаптації до майбутньої професійної діяльності студентів.

Особливістю програми Г.М. Кацавець є інтеграція лекційних і практичних занять, що, на думку авторки, «не втомлює студентів; не викликає монотонного плину часу; не обтяжує сприймання теми, але викликає жвавий інтерес до її обговорення» (Паламар Л., Кацавець Г., 1993, с. 295).

Щодо змістового наповнення курсу, то на 54 години відведено значний, на наш погляд, лінгвістичний блок, зокрема графіки, орфографії, фонетики, лексикології, діалектології, фразеології, словотвору, морфології, синтаксису та пунктуації. Поряд з цим пропонується розгляд найпоширеніших видів документів (по одному на кожне заняття) та специфіки усного ділового спілкування. Я показує практика, така насиченість програми спричиняє деякі труднощі в їі реалізації, а саме:

1. Концентрований лінгвістичний блок, з одного боку, покликаний вдосконалити мовні знання студентів, а 3 іншого, - таке вдосконалення стає можливим за умови якісної шкільної підготовки. В основному це реально на факультетах філологічного спрямування, де викладається дисципліна «Сучасна українська мова», а отже, зникає потреба дублювати матеріал.

2. Для студентів-нефілологів, лінгвістичні знання і вміння яких потребують значного вдосконалення, насиченість програми курсу «Українське ділове мовлення» значно ускладнює цей процес, оскільки потребує початкової актуалізації знань, а потім введення їх у діловий контекст. Таке завдання важко виконати в межах двох програмових годин, відведених на кожну тему.

Варто підкреслити, що автори програм і підручника не окреслюють чітко коло їх призначення, вважаючи курс універсальним, придатним для читання студентам будь-якої спеціальності. Також у програмах пропонується окреме заняття на тему «Банківська діяльність» із ремаркою про можливість підготовки замість нього заняття стосовно специфіки професійної діяльності в конкретній сфері.

Виходячи з поставленої мети курсу: «підвищити грамотність студентів на основі здобутих лінгвістичних знань; сформувати необхідні навички володіння науковим та офіційно-діловим стилем; навчитися укладати і правильно оформляти найпоширеніші офіційні папери, з якими студенти зустрічатимуться під час навчання і подальшої професійної діяльності» (Паламар Л., Кацавець Г., 1993, с. 290), вважаємо, що розроблені програми забезпечували її досягнення й відповідали освітнім вимогам кінця XX ст., однак зміст дисципліни «Українське ділове мовлення», з огляду на сучасні освітні вимоги, потребує значної модифікації для формування усного й писемного професійного мовлення з виходом на компетентнісний результат.

Запровадження в закладах вищої освіти курсу «Українське ділове мовлення» викликало дискусію в науковому інформаційному просторі. Вчені переконували, що ні назва, ні зміст нової дисципліни не забезпечують того обсягу знань, який потрібен майбутньому фахівцю. Лунали пропозиції замінити цей курс на дисципліну «Основи професійної мовної підготовки», яка ґрунтувалася б на принципово новому розумінні мети й змісту мовної підготовки фахівців будь-якої сфери. Акцентувалося на здатності оперувати мовою як знаряддям досягнення успіху в професійному середовищі. Цей курс, на думку науковців, призначений допомогти українським освітянам модернізувати гуманітарну освіту студентів нефілологічних спеціальностей (Януш Я., 1999).

Водночас спостерігалася стійка тенденція до зменшення годин на вивчення цього курсу, державний екзамен замінили екзаменом семестровим, а потім заліком. В окремих вищих закладах освіти перейшли на факультативне викладання дисципліни «Українське ділове мовлення» («Ділова українська мова» (ДУМ)) (Погрібний А., 1999). Науковці наголошували на тому, що зміст названого курсу обмежується вивченням окремих документів і основної фахової термінології. В той час, як необхідно формувати комунікативні навички студентів.

У такому контексті окремі фахівці розробляють моделі альтернативних курсів. Зокрема, О. Тищенко пропонує модель курсу «Мова професійного спілкування», зазначаючи, що «володіння професійним спілкуванням - це, поперше, знання власне мови професійного спілкування (крім норм сучасної української літературної мови, знання спеціальної термінології, особливостей побудови синтаксичних конструкцій, тексту тощо), тобто сформованість мовної компетенції; по-друге, уміння використовувати ці знання на практиці, доречно поєднувати вербальні та невербальні засоби спілкування відповідно до ситуації, мети, тобто сформованість комунікативних навичок» (Тищенко О., 2003, с. 56). Концепція Я. Януш ґрунтується на перевагах лексичної роботи, орієнтованої на професійну й офіційно-ділову сферу. Професорка, крім основних розділів, подає матеріали з культури мови, історії української мови та діловодства, термінознавства, стилістики (Януш Я., 1999).

Спостерігається також термінологічний різнобій у найменуванні дисципліни. За період 2000-2010 рр. виходили друком підручники й посібники з факультативними назвами: «Ділова українська мова», “Ділова українська мова й культура мовлення», «Українська мова у професійному спілкуванні», «Українська мова професійного спілкування», «Мовлення ділових людей на нарадах, засіданнях, зборах», «Культура фахового мовлення», «Українське ділове мовлення: професійне і непрофесійне спілкування», «Українське ділове мовлення», «Мова ділових паперів», «Культура ділової комунікації», «Українська мова в професійній діяльності» та інші.

На виконання постанови Кабінету Міністрів України № 998 від 08.09.1997 «Про затвердження комплексних заходів щодо всебічного розвитку і функціонування української мови» (п.3, напрям 1 «розроблення найновіших концепцій викладання української мови») (Постанова КМУ № 998, 1997) зміст навчальної дисципліни «Ділова українська мова» 
потрапляє в поле досліджень науковців. Так, С. Дорошенко розробляє концепцію дисципліни «Українська мова (за професійним спрямуванням)», наголошуючи на тому, що попередній курс “своєю назвою обмежував можливості прищеплення навичок володіння літературною мовою в спеціальній сфері її застосування» (Дорошенко С., 2004). Щодо змісту дисципліни, то автор підкреслює важливість уникнення повторення в ньому академічного курсу української мови, оскільки «його призначення - вузькоспрямоване: прищепити майбутнім фахівцям-нефілологам навички використання української мови в професійному вжитку» (Дорошенко С., 2004).

Специфікою концепції С. Дорошенка було: 1) практичне спрямування курсу; 2) трикомпонентність програми (культура мовлення, грамотність, професійне мовлення); 3) методика комплексного вивчення всіх компонентів програми (практичне застосування елементів культури мовлення й писемної грамотності в професійному усному й писемному мовленні). На нашу думку, така побудова змісту УМзаПС значно розширювала можливості щодо створення навчального середовища, максимально наближеного до майбутньої професійної діяльності, а відтак мотивації студентів до самовдосконалення.

Дискусії в науковому середовищі призвели до інтенсифікації роботи в правовому полі. 16 лютого 2009 року вийшло розпорядження МОН України № 26-р «Про проведення Всеукраїнської наради з питань викладання дисципліни «Українська мова (за професійним спрямуванням)» у вищих навчальних закладах» (Розпорядження МОН № 26-р, 2009). На його виконання 17 березня 2009 року проведена нарада й підготовлено пропозиції щодо вдосконалення викладання дисципліни «Українська мова (за професійним спрямуванням)» у вищих навчальних закладах.

17 квітня 2009 року МОН України видало Наказ № 341 «Про затвердження Плану дій щодо вдосконалення викладання дисципліни «Українська мова (за професійним спрямуванням)» (Наказ МОН № 341, 2009). Доданий до наказу План передбачав розробку нових навчальних програм інтегрованої дисципліни «Українська мова (за професійним спрямуванням)» для освітньо-кваліфікаційних рівнів молодшого спеціаліста, бакалавра, спеціаліста, магістра, 3 наповненням змісту відповідно до фаху. Крім цього, формування такої програми було заплановано для закладів післядипломної педагогічної освіти. Передбачалося внесення змін до галузевих стандартів вищої освіти з віднесенням дисципліни «Українська мова (за професійним спрямуванням)» до нормативних навчальних дисциплін в обсязі, визначеному навчальною програмою, проведення семестрового контролю та державної атестації у формі екзамену.

Наказом МОН України № 642 від 09.07.2009 «Про організацію вивчення гуманітарних дисциплін за вільним вибором студента» (Наказ МОН № 642, 2009) УМзаПС затверджено як нормативну дисципліну обсягом 3 кредити ECTS (починаючи з прийому 2009 року).

Міністр освіти й науки України І.В. Вакарчук наказом № 1150 від 21.12.2009 р. затвердив програму навчальної дисципліни «Українська мова (за професійним спрямуванням)» для вищих навчальних закладів, що здійснюють підготовку фахівців за освітньо-кваліфікаційним рівнем бакалавра (укладачі: С. В. Шевчук, І. В. Клименко) (Наказ MOH № 1150, 2009).

Наказом МОН від 29 березня 2010 року № 259 внесено зміни до попередніх нормативних актів, зокрема: «Вид контролю: залік (3-й семестр), екзамен (4-й семестр), залік, курсова робота (5-й семестр), державний екзамен» замінити на „Вид контролю: залік (3-й семестр), залік (4-й семестр), екзамен (5-й семестр)” (Наказ МОН № 259, 2010).

Відповідно до затвердженої програми, структура навчальної дисципліни «Українська мова (за професійним спрямуванням)» передбачала вивчення 3-х змістових модулів протягом 3-х семестрів (3-го, 4-го, 5-го) із загальною кількістю 108 год (лекції - 18 год, практичні заняття - 54 год, самостійна робота - 36 год) (Наказ МОН № 1150, 2009).

Еволюційні аспекти змісту УМзаПС виявили себе через спрямування його на формування мовної особистості 3 набором знань, умінь і навичок «оптимальної мовної поведінки в професійній сфері» (Наказ МОН № 1150, 2009). Щодо лінгвістичних знань, отриманих у школі, то вони підлягали узагальненню й систематизації в професійному контексті, але без дублювання. Загальне спрямування курсу УМзаПС у затвердженій програмі визначалося на основі рекомендацій, спільних для всіх сфер фахової комунікації.

Обравши за мету УмзаПС «підвищення рівня загальномовної підготовки, мовної грамотності, комунікативної компетентності студентів, практичне оволодіння основами офіційно-ділового, наукового, розмовного стилів української мови, що забезпечить професійне спілкування на належному мовному рівні» (Наказ МОН № 1150, 2009), розробники програми закріплюють у змісті дисципліни теми «Основи культури української мови», «Спілкування як інструмент професійної діяльності», «Риторика і мистецтво презентації», «Культура усного фахового спілкування», «Форми колективного обговорення професійних проблем», які були відсутні в курсі «Ділова українська мова». Збільшена кількість годин на вивчення УМзаПС дала можливість звернути посилену увагу на специфіку усного професійного спілкування, забезпечивши таким чином формування комунікативної компетентності студентів.

Блок тем, спрямований на засвоєння особливостей писемної професійної комунікації, вирізняється чіткою організацією та структуруванням. Зокрема, з'являється ввідна узагальнена тема «Ділові папери як засіб писемної професійної комунікації», побудована за чинним ДСТУ 4163-2003 «Уніфікована система організаційно-розпорядчої документації. Вимоги до оформлювання документів» (ДСТУ 4163, 2003). Ця тема необхідна для загального розуміння сутності, призначення й класифікації документів, вимог до їх структури й оформлення. Вивчення типової документації згруповано за призначенням, що полегшує студентам розуміння професійних ситуацій її застосування.

Суттєвим показником еволюційних змін у змісті УМзаПС було введення в типову програму змістового модуля «Наукова комунікація як складова фахової діяльності», в якому закріплено теми «Українська термінологія в професійному спілкуванні», «Науковий стиль і його засоби у професійному спілкуванні», «Проблеми перекладу і редагування наукових текстів». Введений змістовий модуль охопив важливий аспект формування професійного мовлення майбутніх фахівців, який досі був проігнорований. Адже прогрес у будь-якій сфері суспільного життя 
неможливий без розвитку науки. Формування професійного мовлення студентів у науковому аспекті охоплює систему фахової термінології, роботу з термінологічними словниками, опанування особливостями наукового тексту й професійного наукового викладу думки, оформлення результатів наукової діяльності тощо.

2011 року на основі типової програми дисципліни «Українська мова (за професійним спрямування)», затвердженої наказом МОН України від 21.12.2009 № 1150, укладено підручник (автори: С. В. Шевчук, І. В. Клименко), який відтоді функціонував як базовий підручник для навчання УМзаПС студентів усіх спеціальностей. Порівняльний аналіз змісту цього видання та попередніх підручників з ділової української мови (з варіативними назвами) дав можливість виокремити суттєві еволюційні зміни в курсі УМзаПС, які узагальнено на рис. 1.

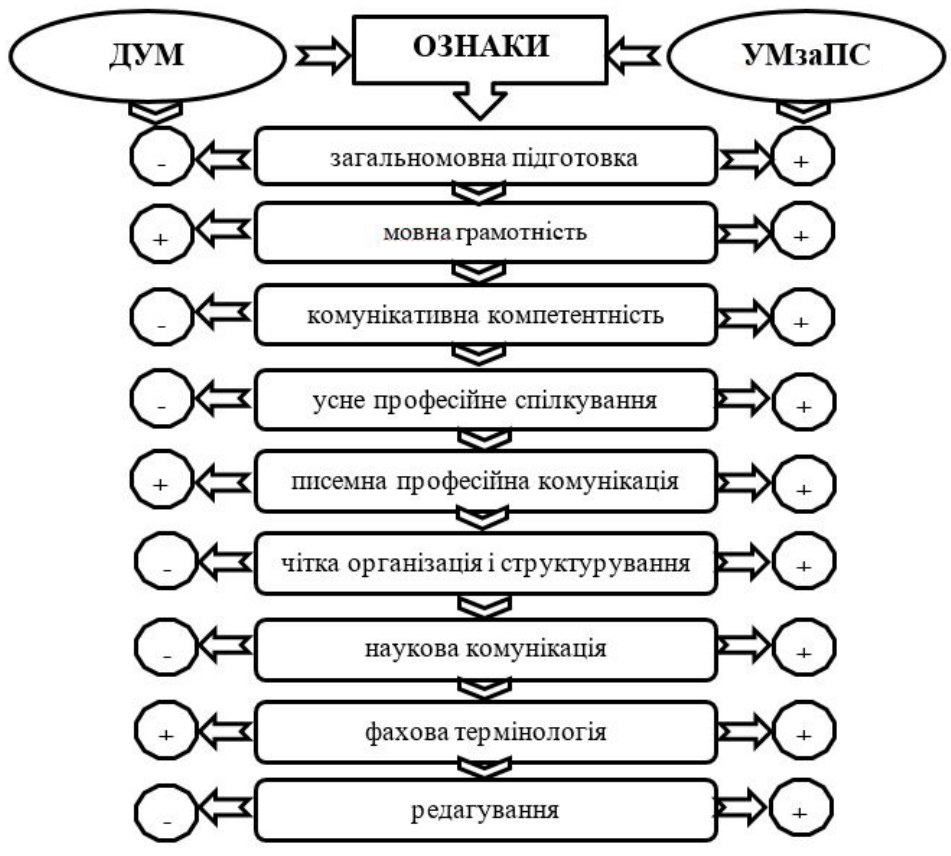

Рис. 1. Порівняльна характеристика змісту навчання ділової української мови (Дум) та української мови за професійним спрямуванням (УМзаПС)

Як видно з рис. 2.3, відбулося кількісне і якісне розширення змісту навчання УМзаПС порівняно з дУМ. Прикметною ознакою реалізації змісту УМзаПС стала орієнтація на формування комунікативної компетентності студентів шляхом вдосконалення вмінь і навичок усного й писемного професійного мовлення на основі інтегрування систематизованих й узагальнених знань з академічного курсу української мови в прогнозований професійний контекст. Кількісне розширення інформації відбулося за рахунок введення тем, які торкалися специфіки усного професійного спілкування й культури мовлення, що теж було цілком обґрунтовано, оскільки «майбутнім фахівцям мова потрібна не як сукупність правил, а як система світобачення, засіб культурного співжиття в суспільстві, самоформування і самовираження особистості» (Наказ МОН № 1150, 2009).

Однак екстенсивне розростання змісту УМзаПС невдовзі зазнало нової трансформації. У зв'язку із запровадженням у вищих навчальних закладах України Європейської кредитно-трансферної системи (Наказ МОН № 943, 2009) кредити ЄКТС обсягом 36 годин, які були запроваджені наказом Міністерства освіти і науки України від 20 жовтня 2004 року № 812 (Наказ МОН № 812, 2004), замінюються на кредити ЄКтС обсягом 30 годин. Відповідно зменшилася кількість годин, відведених для вивчення курсу УМзаПС: 3 кредити становили 90 годин.

Незважаючи на очевидні переваги оновленого змісту нормативного курсу УМзаПС, його теж піддали критиці. Зокрема, О. Доценко висвітлює як негативну розбіжність задекларовані в типовій програмі УМзаПС завдання вищої школи та вивчення специфіки усного й писемного професійного мовлення. Дослідниця знову робить акцент на лінгвістичній підготовці студентів-нефілологів (як у ДУМ), наголошуючи: «Проте майже третину аудиторних годин програмою передбачено на вивчення особливостей оформлення документів і різних форм усного спілкування («мозкового штурму», ділової бесіди тощо)» (Доценко О., 2015).

Лященко М., розглядаючи УМзаПС як складову лінгвістичної освіти майбутніх учителів початкових класів, водночас стверджує: «Проте дисципліна «Українська мова за професійним спрямуванням» на сьогодні не спроможна забезпечити реалізацію поставлених перед нею навчальних завдань, оскільки шкільна мовна підготовка більшості студентів є доволі невисокою» (Лященко М., 2014, с. 47-48).

Закріплення дисципліни «УМзаПС» як нормативної відкрило ширші можливості для україномовної підготовки студентів усіх напрямків навчання. Однак після прийняття Закону «Про вищу освіту» № 1556-VII від 1 липня 2014 року (Закон України «Про вищу освіту», 2014) виникло питання про зміну статусу названого курсу разом з іншими навчальними дисциплінами гуманітарного циклу. МОН України наказом № 1392 від 25.11.2014 скасувало чинність 
наказу МОН України від 09.07.2009 № 642 «Про організацію вивчення гуманітарних дисциплін за вільним вибором студента» (Наказ МОН № 1392, 2014), перевівши таким чином УМзаПС зі статусу нормативної до групи дисциплін, обов'язковість вивчення яких віддається на розсуд ЗВО (Наказ МОН № 1392, 2014). Така нормативна дія створила перешкоди для лінгво-комунікативної підготовки студентів-нефілологів і викликала нову хвилю наукової дискусії.

Так, У. Соловій обґрунтовує обов'язковість викладання УМзаПС у вищих медичних навчальних закладах (Соловій У., 2015, с. 258). Особливий акцент авторка робить на необхідності вивчення професійних аспектів спілкування, виникнення й функціонування фахової термінології, основних принципів наукової комунікації. І. Гаценко наголошує на важливості вивчення курсу УМзаПС майбутніми економістами: «Викладання мовних дисциплін у вищих економічних навчальних закладах не тільки підвищує мовну освіченість студентів і сприяє гуманізації освіти, але й підвищує культурний рівень майбутньої української інтелігенції. Саме на вирішення цієї проблеми й спрямовано курс «Українська мова (за професійним спрямуванням)», у рамках якого відбувається формування комунікативних компетентностей» (Гаценко І., 2013, с. 56).

Необхідність вивчення УМзаПС майбутніми правознавцями обґрунтовує О. Лисенко: проблеми мовної підготовки майбутніх юристів є надзвичайно важливими, оскільки пошук досконалої мовної форми для втілення правового змісту є актуальним науковим завданням для фахівців у галузі правотворчості...» (Лисенко О., 2015, с. 13).

Роль УМзаПС у фаховому становленні студентів вищих закладів освіти аналізує Н. Юрійчук, наголошуючи на взаємозалежності мовної підготовки, специфіки майбутньої спеціальності й рівня кваліфікації: «Зміст дисципліни «Українська мова (за професійним спрямуванням)» має визначатися потребами формування навичок грамотного усного і писемного фахового мовлення, реалізації норм сучасної української літературної мови в різних ситуаціях професійного спілкування. Тому загальна стратегія курсу має бути пов'язана з досягненням мовної компетенції студента в обраній ним професійній сфері, що стає згодом одним з першорядних свідчень фахової зрілості випускника ВНЗ. Отже, йдеться не про звичайне вивчення української мови, а про вивчення мови як форми удосконалення професійних навичок» (Юрійчук Н., 2014, с. 153).

Як бачимо, автори праць у різноспрямованих наукових сферах не піддають сумніву необхідність викладання курсу УМзаПС, підкреслюючи його визначальну роль у підготовці конкурентоздатного фахівця.

\section{ВИСНОВКИ ТА ПЕРСПЕКТИВИ ПОДАЛЬШИХ ДОСЛІДЖЕНЬ}

Таким чином, ретроспективний аналіз змісту навчання УМзаПС показав наявність двох різноспрямованих тенденцій: 1989-1999рр. - декларування переваг лінгвістичного спрямування дисципліни (ДУМ), відходу від діловодства; з 2000 р. до сьогодні - ухилення від академічного лінгвістичного курсу й практична орієнтація на формування професійного мовлення. Перспективним для подальших наукових розвідок вважаємо дослідження актуального статусу УМзаПС у сучасних ЗВО.

\section{СПИСОК ВИКОРИСТАНИХ ДЖЕРЕЛ}

Гаценко, І. О. (2013). Особливості формування мовної особистості майбутнього фахівця у вищому навчальному закладі. Вісник Чернігівського національного педагогічного університету. Педагогічні науки, 111, 56-59. URL: http://nbuv.gov.ua/UJRN/ VchdpuP_2013_111_16

Дорошенко, С. (2004). Новій навчальній дисципліні - нову концепцію. Вісник Сумського державного університету. Філологічні науки, 1(60), 5-8. URL: https://essuir.sumdu. edu.ua/ handle/123456789/10852

Доценко, О. Л. (2015). Формування мовної та комунікативної компетентностей студентів нефілологічних спеціальностей. Освітологічний дискурс, 2 (10), 109-116. URL: http://oaji.net/articles/2016/2923-1456732050.pdf

Лисенко, О.А. (2015). Мовна підготовка студентів юридичних спеціальностей відповідно до болонської системи освіти. Наукові записки Національного університету «Острозька академія». Серія «Філологічна», 58, 11-13. URL: https://lingvj.oa.edu.ua/ articles/2015/n58/6.pdf

Лященко, М. (2014). Українська мова за професійним спрямуванням як складова лінгвістичної освіти майбутніх учителів початкових класів. Початкова школа, 5, 47-49.

Паламар, Л.М., Кацавець, Г.М. (1993). Мова ділових паперів : навчальний посібник для студентів ВНЗ. Київ : Либідь.

Погрібний, А. (1999). Державна мова і вища школа в сучасній Україні. Освіта, 28 квітня - 5 травня, 12-19 травня; 26 травня.

Про визнання таким, що втратив чинність, наказу Міністерства освіти й науки України від 09.07.2009 № 642. Наказ МОН України від 25.11.2014 № 1392. URL: http://document.ua/pro-viznannja-takim-sho-vtrativ-chinnist-nakazu-ministerstva-doc211290.html

Про вищу освіту. Закон України № 1556-VII від 1 липня 2014 року. Перша редакція. URL: https://zakon.rada.gov.ua/rada/show/ $\mathrm{ru} / 1556-18 / \mathrm{ed} 20140701$

Про внесення змін до наказів MOH від 09.07.2009 № 642 та від 21.12.2009 № 1150. Наказ MOH України № 259 від 29.03.2010. URL: https://osvita.ua/legislation/Vishya_osvita/7095/

Програма курсу «Українська мова (за професійним спрямуванням)». Наказ Міністерства освіти і науки України від 21 грудня 2009 року № 1150 (Зі змінами внесеними згідно наказу MOH № 259 від 29.03.2010). URL: https://osvita.ua/legislation/ Vishya_osvita/7095/

Про запровадження у вищих навчальних закладах України Європейської кредитно-трансферної системи. Наказ МОН № 943 від 16 жовтня 2009 року. URL: http://tnpu.edu.ua/EKTS/N_zaprov_EKTS.pdf

Про затвердження комплексних заходів щодо всебічного розвитку і функціонування української мови. Постанова Кабінету Міністрів України від 8 вересня 1997 року № 998. Київ. URL: https://zakon.rada.gov.ua/laws/show/998-97-\%D0\%BF

Про затвердження Плану дій щодо вдосконалення викладання дисципліни «Українська мова (за професійним спрямуванням). Наказ MOH України № 341 від 17.04.2009. URL: http://tc.terminology.lp.edu.ua/TK_Work/MON_2009_N341.htm

Про організацію вивчення гуманітарних дисциплін за вільним вибором студента. Наказ МOH України № 642 від 09.07.2009. URL: https://osvita.ua/legislation/Vishya_osvita/6122/ 
Про особливості впровадження кредитно-модульної системи організації навчального процесу. Наказ МОН № 812 від 20.10 .2004 . URL: https://zakononline.com.ua/ documents/show/28597_28597

Про проведення Всеукраїнської наради з питань викладання дисципліни «Українська мова (за професійним спрямуванням)» у вищих навчальних закладах». Розпорядження МOH України № 26-р від 16.02.2009. URL: https://osvita.ua/legislation/ Vishya_osvita/3103/

Соловій, У. (2015). Проблемні аспекти викладання навчальної дисципліни «Українська мова (за професійним спрямуванням)» у вищих медичних навчальних закладах. Педагогіка вищої та середної школи, 44, 256-260.

Тищенко, О. (2003). Модель курсу «Мова професійного спілкування». Дивослово, 3, 30-56.

Уніфікована система організаційно-розпорядчої документації. Вимоги до оформлювання документів. ДСТу 4163-2003. Затверджено наказом Держспоживстандарту України від 7 квітня 2003 р. № 55. URL: http://www.vru.gov.ua/content/file/Doc_007.pdf

Юрійчук, Н. (2014). Роль української мови (за професійним спрямуванням) у фаховому становленні студентів ВНЗ. Теоретична і дидактична філологія, 18, 150-154. URL: http://nbuv.gov.ua/UJRN/Tidf_2014_18_33

Януш, Я. (1999). Українська мова в економічному вузі. Дивослово, 2, 9-14.

\section{REFERENCES}

Ghacenko, I. O. (2013). Osoblyvosti formuvannja movnoji osobystosti majbutnjogho fakhivcja u vyshhomu navchaljnomu zakladi. Visnyk Chernighivsjkogho nacionaljnogho pedaghoghichnogho universytetu. Pedaghoghichni nauky, 111, 56-59. URL: http://nbuv.gov.ua/UJRN/ VchdpuP_2013_111_16

Doroshenko, S. (2004). Novij navchaljnij dyscyplini - novu koncepciju. Visnyk Sumsjkogho derzhavnogho universytetu. Filologhichni nauky, 1(60), 5-8. URL: https://essuir.sumdu. edu.ua/handle/123456789/10852

Docenko, O. L. (2015). Formuvannja movnoji ta komunikatyvnoji kompetentnostej studentiv nefilologhichnykh specialjnostej. Osvitologhichnyj dyskurs, 2 (10), 109-116. URL: http://oaji.net/articles/2016/2923-1456732050.pdf

Lysenko, O.A. (2015). Movna pidghotovka studentiv jurydychnykh specialjnostej vidpovidno do bolonsjkoji systemy osvity. Naukovi zapysky Nacionaljnogho universytetu «Ostrozjka akademija». Serija «Filologhichna», 58, 11-13. URL: https://lingvj.oa.edu.ua/ articles/2015/n58/6. pdf

Ljashhenko, M. (2014). Ukrajinsjka mova za profesijnym sprjamuvannjam jak skladova linghvistychnoji osvity majbutnikh uchyteliv pochatkovykh klasiv. Pochatkova shkola, 5, 47-49.

Palamar, L.M., \& Kacavecj, Gh.M. (1993). Mova dilovykh paperiv : navchaljnyj posibnyk dlja studentiv VNZ. Kyjiv : Lybidj.

Poghribnyj, A. (1999). Derzhavna mova i vyshha shkola v suchasnij Ukrajini. Osvita, 28 kvitnja - 5 travnja, $12-19$ travnja; 26 travnja.

Pro vyznannja takym, shho vtratyv chynnistj, nakazu Ministerstva osvity j nauky Ukrajiny vid 09.07.2009 \# 642. Nakaz MON Ukrajiny vid 25.11.2014 \# 1392. URL: http://document.ua/ pro-viznannja-takim-sho-vtrativ-chinnist-nakazu-ministerstva-doc211290.html

Pro vyshhu osvitu. Zakon Ukrajiny \# 1556-VII vid 1 lypnja 2014 roku. Persha redakcija. URL: https://zakon.rada.gov.ua/rada/show/ru/1556-18/ ed20140701

Pro vnesennja zmin do nakaziv MON vid 09.07.2009 \# 642 ta vid 21.12.2009 \# 1150. Nakaz MON Ukrajiny \# 259 vid 29.03.2010. URL: https://osvita. ua/legislation/Vishya osvita/7095/

Proghrama kursu «Ukrajinsjka mova (za profesijnym sprjamuvannjam)». Nakaz Ministerstva osvity i nauky Ukrajiny vid 21 ghrudnja 2009 roku \# 1150 (Zi zminamy vnesenymy zghidno nakazu MON \# 259 vid 29.03.10 roku). URL: https://osvita.ua/legislation/Vishya_osvita/7095/

Pro zaprovadzhennja u vyshhykh navchaljnykh zakladakh Ukrajiny Jevropejsjkoji kredytno-transfernoji systemy. Nakaz MON \# 943 vid 16 zhovtnja 2009 roku. URL: http://tnpu.edu.ua/EKTS/N_zaprov_EKTS.pdf

Pro zatverdzhennja kompleksnykh zakhodiv shhodo vsebichnogho rozvytku i funkcionuvannja ukrajinsjkoji movy. Postanova Kabinetu Ministriv Ukrajiny vid 8 veresnja 1997 roku \# 998. Kyjiv. URL: https://zakon.rada.gov.ua/laws/show/998-97-\%D0\%BF

Pro zatverdzhennja Planu dij shhodo vdoskonalennja vykladannja dyscypliny «Ukrajinsjka mova (za profesijnym sprjamuvannjam). Nakaz MON Ukrajiny \# 341 vid 17.04.2009. URL: http://tc.terminology.lp.edu.ua/TK_Work/MON_2009_N341.htm

Pro orghanizaciju vyvchennja ghumanitarnykh dyscyplin za viljnym vyborom studenta. Nakaz MONN Ukrajiny \# 642 vid 09.07.2009. URL: https:// osvita.ua/legislation/Vishya_osvita/6122/

Pro osoblyvosti vprovadzhennja kredytno-moduljnoji systemy orghanizaciji navchaljnogho procesu. Nakaz MON \# 812 vid 20.10.2004. URL: https:// zakononline.com.ua/ documents/show/28597_28597

Pro provedennja Vseukrajinsjkoji narady z pytanj vykladannja dyscypliny «Ukrajinsjka mova (za profesijnym sprjamuvannjam)» u vyshhykh navchaljnykh zakladakh». Rozporjadzhennja MON Ukrajiny \# 26-r vid 16.02.2009. URL: https://osvita.ua/ legislation/Vishya_osvita/3103/

Solovij, U. (2015). Problemni aspekty vykladannja navchaljnoji dyscypliny «Ukrajinsjka mova (za profesijnym sprjamuvannjam)» u vyshhykh medychnykh navchaljnykh zakladakh. Pedaghoghika vyshhoji ta serednoji shkoly, 44, 256-260.

Tyshhenko, O. (2003). Modelj kursu «Mova profesijnogho spilkuvannja». Dyvoslovo, 3, 30-56.

Unifikovana systema orghanizacijno-rozporjadchoji dokumentaciji. Vymoghy do oformljuvannja dokumentiv. DSTU 4163-2003. Zatverdzheno nakazom Derzhspozhyvstandartu Ukrajiny vid 7 kvitnja 2003 r. \# 55. URL: http://www.vru.gov.ua/content/file/Doc_007.pdf

Jurijchuk, N. (2014). Rolj ukrajinsjkoji movy (za profesijnym sprjamuvannjam) u fakhovomu stanovlenni studentiv VNZ. Teoretychna i dydaktychna filologhija, 18, 150-154. URL: http://nbuv.gov.ua/UJRN/Tidf_2014_18_33

Janush, Ja. (1999). Ukrajinsjka mova v ekonomichnomu vuzi. Dyvoslovo, 2, 9-14.

Статтю подано до редколегії 12.03 .2020 р.

Рекомендовано до друку 29.03.2020 p. 